\title{
How Malevolent Gatekeepers Exacerbate the Power Imbalance in Social Research \\ Craig W.J. Minogue
}

\section{INTRODUCTION}

In this article I outline the history of research ethics, starting with the issues that arise from imbalanced power relations. I then analyse the national social research ethics policy in Australia, which is typical of such policies in developed countries, and identify one of its significant shortcomings. I argue that not all institutional gatekeepers are equal and can be assumed to have an ethical research policy. I differentiate between benevolent and malevolent gatekeepers, and analyse the research policy of a malevolent gatekeeper in the form of Corrections Victoria/Department of Justice in Australia. I propose an innovative solution that will ethically enhance and considerably broaden academic research practices and outcomes whilst bypassing a malevolent gatekeeper, and what I argue is its unethical research governance. I conclude by asking whether researchers are willing to think critically or simply follow codes of research ethics and the power of institutional gatekeepers without a proper consideration of the ethical consequences of their actions.

\section{IN THE BEGINNING}

In his seminal 1972 article exploring the ethical considerations associated with power relations between institutions, researchers, and participants in social research, Herbert C. Kelman (1972, p. 1011) ${ }^{1}$ argues that:

The questioning of the status quo, of the assumptions on which existing social institutions and policies are based, is at the very heart of the analysis in which the social scientist engages and is inherent in [their] methodology. Social science, by its nature, is designed to bring independent analytic perspectives to bear on questions of social policy and to provide systematic bases for assessing the consequences of existing arrangements and deriving alternative policy approaches.

At the time Herbert Kelman's article was published, there was considerable thought being given to the role of research ethics within social institutions. Tremendous controversy surrounded Stanley Milgram's (1974) obedience 
experiments. Philip Zimbardo had conducted the Stanford Prison Experiment which went out of control when the student participants, playing prison officers, started to abuse their fellows acting as the prisoners, who in turn started to resist violently or became almost catatonically withdrawn (Haney et al., 1973). The filming of these experiments, which allowed the widespread dissemination of the shocking results, contributed to an assumption that maverick experimenters needed to be reined in by Institutional Review Boards (Research Ethics Committees in Australia) and government-sponsored national ethical research standards. Of course, it is legitimate and appropriate for there to be codes of ethical research standards and ethical oversight of research. I argue, however, that the practices associated with institutional control over academic research involving human persons have become an unquestioned part of the research landscape which academics respond to in a formulaic way. Participant consent forms have become a kind of fetishism, despite the fact that some researchers think they are detached from reality and almost threatening. ${ }^{2}$

In matters of academic research, the role of institutional gatekeepers, like hospitals, schools, and prisons, is to protect research subjects or participants from being harmed by the research process and to ensure that researchers do not interfere with legitimate institutional activities. A review of the literature available to me (see endnote 2) suggests that the legitimacy of the role gatekeepers play and their governance of the social research process is not subject to the critical analysis it deserves.

In Australia, the National Statement on Ethical Conduct in Human Research (NSECHR) is the key policy document for social researchers and Human Research Ethics Committees. The National Statement uncritically emphasizes the role of institutional gatekeepers and it therefore accepts an assumption, as does most of the literature, that gatekeepers are naturally benign, objective, and enlivened to the public and personal good in determining issues of governance and control of research within their areas of responsibility (NSECHR, 2007, p. 4). The National Statement also presumes that the role of a researcher is to act as an adjunct to, or under the auspices of, the institution (NSECHR, 2007, p. 4). The very clear implication of the policy in the National Statement is that institutions can be trusted, but researchers cannot. I believe there is a kind of "four legs good, two legs bad" ideology at work here. 
The underlying mission of ethics, philosophy and the social sciences is to challenge ideological positions that situate the Other at a disadvantage because of an arbitrary attribute which marks their Otherness. The ethical value of our conduct needs to be thought through, because history has shown that there is a very real danger in uncritically accepting the basic assumptions of one's epoch, be they cultural, racial or political. I argue that the idea that institutional gatekeepers are benign is based on such an assumption. Philosophers ought to investigate and critically think about the positions for which there may well be no rational justification. Peter Singer (1986, p. 225), the author of Animal Liberation, has argued that "thinking

through, critically and carefully, what most people take for granted is, I believe, the chief task of philosophy".

Institutional governance of research ethics and the development of codes of research ethics both internationally and nationally, constituted a very appropriate and necessary response to the horrors of Nazi death camps and other bio-medical research atrocities like the Tuskegee Syphilis Study and the Willowbrook State Hospital study involving hepatitis in the United States. Over time, the primacy of the institution as a research gatekeeper has become a basic assumption that is not ethically interrogated. Despite the fact that the legitimacy of institutional gatekeepers is uncritically accepted, I am proceeding on the basis that all areas of research ethics should be critically thought through in an ongoing way. When the role of institutional gatekeepers is thought through, it becomes clear that benevolent and malevolent gatekeepers need to be differentiated along with the various ethical positions that arise.

\section{ARE ALL GATEKEEPERS EQUAL?}

When considering social institutions in general - that is, before we look at their research ethics processes - it can be said that a benevolent gatekeeper is found, for example, in the hospital or school, as their primary mission is to provide benefit by caring for and improving the health of patients or to provide an education for pupils. When approached by researchers seeking access to the patients and pupils, the hospital and the school have a primary ethical duty to promote the specific interests of their patients and pupils. This is not to say that the institutions themselves or their Ethics Committees are benevolent in all things when it comes to their patients and pupils. Benevolence is a fair starting point with these types of institutions. 
A malevolent gatekeeper, on the other hand, can be found in the prison, whose primary mission is to hold prisoners coercively to serve the utilitarian end of punishment as part of the criminal justice system. The prison has a legal duty to care for the welfare of prisoners, but this duty is legally and ethically subservient to matters of security and control, as they are judged to be relevant and at the discretion of individual staff members of the institution. When approached by researchers seeking access to prisoners, the ethical duty of the prison for the people over whom they have a gatekeeping role is nowhere near as clear-cut as the duty of the hospital or school in promoting the specific interests of the people concerned.

A prisoner with two days or two decades of a sentence to serve can legally be shot and killed if trying to escape custody. The prison has absolute control over every aspect of the physical environment in and near the prison. The body of the prisoner is also controlled, not only to the extent that movements around the institution can be limited to very small and physically confining spaces, but to the point that the physical integrity of the prisoner's body can be violated and intimately examined without consent and even against the well-articulated objections of the prisoner. Firearms, chemical weapons, pain-inflicting instruments of restraint, attack dogs, striking weapons and electroshock weapons are all standard equipment used to coerce prisoner compliance (Minogue, 2005; Minogue, 2010, p. 323). There is no civil agreement between prisoners and the prison, no consent is sought or given at any point, and there is no proportionality of coercive action. Rather, a military level of absolute and 'life-threatening force' underpins the everyday practices which the prison aggressively deploys as a means of compelling the total compliance of prisoners to the will of individual officers and the institution as a whole (Minogue, 2005).

A patient seeking to leave a hospital against medical advice, or a pupil who is truant or remiss in their lessons, cannot be shot and killed or coerced violently in the way which it is thought legitimate to treat a prisoner. A case study will help to illustrate this point. A short-term prisoner in Victoria, Australia was shot in the neck as he, in a state of "desperation," while handcuffed, ran down what an escorting prison officer knew to be a deserted, dead-end and underground corridor in a public hospital (DPP v Federico [2005] p. 605). Claiming he feared for his life and the lives of other people in the crowded hospital as the prisoner ran away from him, the prison officer fired a number of shots at the prisoner, one of which hit the man in the 
neck and killed him. The judge ordering the acquittal of the prison officer on a charge of murder said that the handcuffs, an "authorized instrument of restraint" at corrections law, which were securing the man's wrists, were to be considered in the defense to charge of murder, as "a weapon" which could have been used to "wreak havoc" on the general public (ibid, p. 606). The verb to "wreak" means "to inflict or execute vengeance, etc., to carry out the promptings of one's rage, ill humour, will, desire etc., as on a victim or object" (The Macquarie Dictionary, 1981, p. 2006). The Macquarie Dictionary is the Australian national dictionary, and it should be turned to when interpreting legislation (Gifford and Gifford, 1994, p. 89). The noun "havoc" means to cause "devastation; ruinous damage; to ruin; destroy; a word used as the signal for pillage in warfare" (ibid, p. 816). The phrase crier havot (cry havoc) was used to "give the call for pillaging" (ibid). The word "pillage" means "to strip of money and goods by open violence, as in war; plunder; to take as booty etc." (ibid, p. 1311). Exactly how a prisoner, in a deserted, dead-end and underground corridor, could wreak havoc by the instruments of restraint which were securing his wrists is not explained in the judgment.

Then, in a hypothetical and unsustainable leap of logic, the judge in this case found that the escaping prisoner running down the deserted, dead-end and underground corridor, away from the man with the gun, could have "commandeered a lethal firearm" (DPP v Federico, [2005] p. 606). Perhaps the prisoner could have stumbled upon the weapon-stocked armory, which the hospital keeps to coercively control its patients? Of the two escorting prison officers, only one had a firearm. The prison officer said he acted immediately and "instinctively and in accordance with his training", drew his firearm and started shooting (ibid). Given the immediate nature of the shots discharged at the prisoner, it is very difficult to imagine how the prisoner could have commandeered any firearm, let alone the officer's firearm whose bullets were aimed and fired at the prisoner's head (ibid). The power of prison officers escorting a prisoner outside of the prison, like the powers they have inside the prison, are effectively unfettered and absolute - officers are empowered to do 'anything' or to 'order' a prisoner to do 'anything' the individual officer deems necessary to control the prisoner and the situation (Parliament of Victoria [1986] Corrections Act, ss.9A (1B) (c)(i) and $55 \mathrm{C}(2)(\mathrm{a})$ ). This judgment does not speak to reason or logic, but to the lowly status of a prisoner as an Other and to the absolute power of a prison officer at law to do as he or she subjectively sees fit. 
This case illustrates that the use of force by prison staff - in Victoria at least, and most other places no doubt - is not accompanied by reason or fairness, sensibility, appropriateness or proportionality. Ethical action is, by its very nature, endowed with reason and sound judgement which can be shown to not exceed the limits prescribed by reason or fairness. Reason is not characterized by excess. Rather, it is characterized by that which is moderate in the circumstances.

The unassailable reality is that the modalities of control in the prison setting are far beyond what is reasonable, lawful or ethical for a benevolent gatekeeper. For in a benevolent institution, ongoing civil consent of the patient or the parents of the pupil is required for any physical restrictions, pain and suffering, or loss of privacy. And the physical restrictions, pain and suffering, or loss of privacy in a benevolent institution represent the minimum of what is reasonably required and demonstrably necessary in the circumstances to achieve a beneficial outcome from the person concerned - none of this is in any way true of the prison, a malevolent institution. Significantly, these institutions play the role of gatekeepers when researchers seek access to people within them.

\section{ANALYSING THE RESEARCH POLICY OF A MALEVOLENT GATEKEEPER}

Having differentiated between a benevolent and a malevolent gatekeeper, it can be seen that a very different set of ethical considerations must apply for social researchers. The very nature of the prison as a malevolent gatekeeper means that its vested institutional interests will most often violently override and contradict the interests of the prisoners. To fully consider the ethical issue inherent in my argument against accepting the research governance of a malevolent gatekeeper at face value it needs to be asked if there is any evidence which would suggest that such institutions allow their nature as a malevolent gatekeeper to undermine the possibility for and conducting of ethically responsible academic research.

There is next to nothing that is new in the theory or practice of the prison. From the Rasphuis of Amsterdam which was opened in 1596, to the so called 'Philadelphia model' which followed suit and applied the same theory and practice to the opening of the Walnut Street Prison in 1790, and a contemporary prison in Victoria, Australia (Foucault, 1991; Minogue, 
2011). In the Australian context, Corrections Victoria and the Department of Justice Victoria (CV-DOJ) represent, in many respects, the typical approach taken in relation to the operating theory and practice of prisons in developed countries. For example, sightseeing tours of prisons taken by academics and students follow the same patterns in Australia as they do in Canada (Minogue, 2009; Piché and Walby, 2010). However, some authors argue that carceral tours in the United States are given more ethical consideration by Institutional Review Boards than they are in Australia and Canada and suggest that the reported conditions in Australia and Canada would constitute a violation of civil rights and lead to litigation (Smith, 2012, p. 3). From an American perspective, Hayden Smith is no doubt right about this violation of civil rights and resulting litigation, but the notions of "civil rights" or "human rights" are not known to Australian law as justifiable rights (Minogue, 2002; Minogue v Human Rights and Equal Opportunity Commission [1998 and 1999]; Minogue v Australia [2004]).

Leaving the issue of carceral tours aside, I want to examine what the gatekeeper says about social research governance. On the CV-DOJ (2011) website, under a page headed "Corrections Victoria - Research Ethics Application Guidelines", it is advised that:

All research to be conducted in a correctional setting requires ethics approval and must receive support from Corrections Victoria prior to being submitted to the Department of Justice Human Research Ethics Committee. When deciding whether Corrections Victoria will support a research project, the Research and Evaluation Unit considers a range of factors, [primarily it considers if the research] aligns to the strategic priorities of the organisation.

CV-DOJ details their research governance and research ethics policy in two documents; the first is the Corrections Research Strategy 2009-2012 and the second is the Corrections Research Agenda 2009-2012, both of which are still current. The Strategy advises that the research goals of Corrections are to "manage research projects that build the strategic capacity of the organisation, improve the outcomes of our work and are of a calibre that enhances our standing in the research and criminal justice communities" (Corrections Research Strategy, 2009, p. 3). The stated "strategic initiative" of the policy is to "leverage Corrections Victoria's research activities to 
enhance its standing as an organization", and "to use research findings to penetrate the media, lead and influence debate on correctional issues" so as to "generate positive media coverage of Corrections Victoria's work" (ibid, p. 5). The Strategy clearly evidences a strong desire for leverage, penetration, and influence, and it paints an aggressive modality of control of the social research process and its outcomes to serve the vested interests of CV-DOJ. The Agenda, however, is not so straightforward as it is couched in densely packed and obtuse corporate language that is difficult to understand. A close reading of the policy can, however, reveal its justification for and the means of controlling research to serve the vested interests of the institution.

The Agenda explains that "correctional facilities operate as a result of complex organisational effort" and that "in view of this, the strategic planning and management cycle was chosen as the organising framework for Corrections Victoria's priority research topics" (Corrections Research Agenda, 2009, p. 6). In their own words, the corporate aim here is to "ensure that our research efforts support the achievement of Corrections Victoria's strategic priorities and yield findings that are useful at both policy and operational levels" (ibid, p. 4, emphasis added). Recall that, in the more direct language of the Strategy, it is a "strategic initiative" to "enhance" Corrections" "standing as an organization" and "penetrate the media" so as to "generate positive media coverage" (Corrections Research Strategy, 2009, p. 5). To side step the obtuse corporate language of the Agenda, in plain terms, it is fair to say that the policy can be reduced to the biased and value-laden question: will this research help us run our prisons, get the results we want, and make us look good in the mainstream news and infotainment media?

The Corrections Research Agenda (2009, p. 7) identifies four areas of research which Corrections will support. These relate to:

- socio-economic issues of crime in the community;

- helping corrections to run its prisons in relation to issues of workforce development, systems and processes, resources, infrastructure and organisational culture;

- understanding prisoners and their needs in order to help "deliver the core business efficiently and effectively"; and

- reviewing the implementation of findings associated with the research aimed at helping corrections to run its prisons. 
Under each of these four research categories, Corrections Victoria states that they believe the "current situation" corresponds to its corporate view, which it then relies upon to formulate and provide a list of pre-approved research questions (ibid, pp. 8-37).

There seems to be very little room for independent academic research here. It is a clearly expressed condition that before a proposal is sent to the DOJ for final consideration by its Research Ethics Committee, it must be endorsed by Corrections, and "research proposals will have the best chance of obtaining Corrections Victoria's endorsement if they are shaped in consultation with relevant staff members" (ibid, p. 38). However, before Corrections starts to shape the research project to suit its strategic initiatives, the researcher needs to have demonstrated "the potential utility of [the] research topic" to serve the organisational and strategic needs of Corrections Victoria to the Research Evaluation Unit (ibid). The utility of the topic is about yielding findings that they find useful. The process looks like this:

- The researcher must demonstrate to the CV Research Evaluation Unit that the research has a utility to Corrections and will produce results that are desired by Corrections.

- If the CV Research Evaluation Unit is satisfied of the potential utility and results of the research, then staff from $\mathrm{CV}$ will work with the researcher to shape the research proposal to best suit the strategic initiatives of Corrections. The research proposal will go back and forth between all the stakeholders and the CV Research Evaluation Unit until the proposal is endorsed. Researchers are told to "allow plenty of time for discussion" for this part of the shaping process (ibid).

- The DOJ Ethics Committee will then consider the proposal for final approval.

No doubt the utility of the topic would be best served if a researcher chooses a Corrections-approved research question provided in the Agenda. Choosing a pre-approved research question, which is framed by what CV-DOJ says is the current socio-economic situation, does not constitute a legitimate social research methodology for an independent, ethically responsible academic. Perhaps it is possible for some researchers to negotiate this situation in 
the preliminary stages so that their research and outcomes are not co-opted by the prison, but then there is the matter of the inherent unequal power relations that underlie the work of researchers operating with the auspices of the powerful gatekeeper when dealing with powerless, dependent and vulnerable subjects/participants. Perhaps these things can be negotiated and perhaps a researcher could do something to address the stark power imbalance. That, however, seems unlikely (Minogue, 2003; Minogue, 2009). If a researcher deals officially with prisoners with the auspices of the institution, then, by the very nature of that situation, the autonomy of participants cannot be respected.

If one considers, as I do, protecting the interests of participants to be the cardinal rule of human research, be that social or medical research, then serious questions are raised by research conducted in the prison pursuant to a policy such as that described above. A researcher who agrees with the public relations-like conditions and control of their research outcomes, and who then acts with the auspices of the malevolent gatekeeper, leaves themselves open to the charge that their work is ethically compromised (Minogue, 2003; Minogue, 2009). The notion that research outcomes might be controlled is not a stretch, as the Agenda makes it clear that research is to "yield findings that are useful at both policy and operational levels" (Corrections Research Agenda, 2009, p. 4). The use of the word "yield" is telling, for a yield is something that is produced or provided as a result of a purposeful process. Most commonly, a yield is understood as a material gain or a profit that relates to a financial return. For an institution to talk about shaping academic research so as to yield findings that are useful for its vested interests devalues academic research and makes it ethically questionable.

At the centre of the social research activity are the power relations between two interrelated people: the researcher and the research subject or participant. It is common ground that prisoners are socially disadvantaged, of poor physical and mental health, and marginalised working class or underclass people who are totally dependent on the good graces of the malevolent institution which holds them against their will. On the other hand, social researchers who come into and go out of the prison setting are most often people from a middle or upper class background with a tertiary education and who are obviously operating with the auspices of the prison. Many academic researchers seem to be totally oblivious to this severe 
power imbalance resulting from their privileged position as researchers, and the powerless and disadvantaged position of the prisoners they study as subjects or whom they work with as participants. The work of C. Fred Alford offers a typical example of the ethically oblivious mindset of some academics in relation to matters of social status, inequality, and the research process. Alford (2000, p. 142), an academic who conducts research in the American prison system, boasts of his likeness to "an unpaid staff member with an official position, that of researcher with... a staff badge" which gives him the freedom to roam around the prison at his self-directed will. And it gets worse as Alford argues that this official position gives his research added credibility and the ability to say what is really going on in the prison in ways that academics without the "staff badge" cannot (ibid).

Research activities are not the only problem at the malevolent institution. As previously mentioned, it was once general practice in Victoria for universities to allow academics and students to participate in guided tours of prisons without an Ethics Committee consideration. The questionable practices associated with prison tours are widespread (Piché and Walby, 2010). When ethics complaints have been raised with universities about this practice, the response has been "the prison allows us to do it", therefore the prison is responsible and there is no need for Ethics Committee consideration (Minogue, 2003). Since complaints to universities in Victoria, Australia detailed in Minogue (2003), the tours have very much diminished in their frequency. Some have argued that prison tours by academics could be conducted ethically and suggested potential amendments to achieve such a goal, but I am unaware of any academics taking up these suggestions (Minogue, 2009). In this paper, rather than argue for an ethical research scheme for academics from outside the prison, I want to suggest something which is much more innovative and ethical.

It is sociological, psychological, and ethnographic research orthodoxy that covert research can be undertaken without informing the subjects. I have not, however, been able to source any peer-reviewed material that addresses the possibility of fully informing participants, but acting covertly from the institutional gatekeeper. The prospect of covert or limited disclosure is contemplated within ethical realms for dealing with subjects/participants (NSECHR, 2007, pp. 8, 23-24). Let me reiterate that I consider protecting the interests and respecting the autonomy of research participants to be the cardinal rule of human research, so I approach any suggestion to abstain 
from informing participants with a great deal of caution. Covert research projects that treat people as subjects of research, rather than respected participants or partners in the research, should be limited to those very few situations where overt disclosure would make the research impossible or the results flawed. But such is the primacy of the role of the gatekeeper that concealing research from or even limiting disclosure to a gatekeeper is not considered in the National Statement.

\section{HOW TO ADDRESS THESE PROBLEMS?}

Before an innovative approach can be taken, there needs to be a willingness on the part of researchers to differentiate between benevolent and malevolent gatekeepers. Then, the particular research governance policy of the gatekeeper needs to be ethically scrutinised rather than uncritically accepted at face value, as is most often the case. Considering the way in which CV-DOJ, as a typical example, seeks to shape and control the results of research for its own vested interest, the possibility of bypassing a malevolent gatekeeper to conduct research covertly while fully informing and respecting participants should be actively considered as the most ethical way to proceed in the prison setting.

Bypassing any gatekeeper to conduct covert research is a bold move. Simply put, relying on a malevolent gatekeeper to give permission may well involve a less ethical outcome for the research participants. And the ethically relevant interests of the participants should come first, not the vested power interests of the institution as represented by its research governance processes. Without gatekeeper approval, a social researcher would need to be much more personally responsible for their ethical conduct, rather than shielded by the gatekeeper.

Criminologists who work with gatekeepers can be heard saying things like "the prison lets me do it-end of ethical discussion". Even academics who admit their ethical unease to the point that they feel like apologising to the prisoners they subject to their research, nevertheless go on to say that any apology "would be incongruous" (Wacquant, 2002, p. 378). Yes, it would be incongruous because the researcher is a privileged actor in an unequal power relationship that he is exploiting, a situation in which he can get away with not considering the ethical imperative to respect the dignity of other human persons. 
I opened this paper with reference to Herbert Kelman's (1972) article wherein he considered issues of power relations and the policies of social institutions. In this article, Herbert Kelman goes on to say that researchers can promote equality by drawing research participants from similar socioeconomic, racial, gender and cultural backgrounds. Herbert Kelman argued that "disadvantaged segments of the population" could be "represented genuinely in the research process" if members of their group were trained as researchers, and that, if this were to happen, "social research would be broadened considerably" and ethically enhanced because social equality would underpin the interactions between researchers and participants (ibid, p. 1014). When a person from within one's own community is conducting the research, then issues of unequal power relationships are greatly reduced. But what about the situation in prisons? Herbert Kelman says that although some groups, like "criminals" in prison, "often provide subjects [they] cannot, by their very nature, provide investigators" (ibid, p. 994). And, consequently, this means there is "an unequal relationship [in the research process], since there is no real possibility of role reversal" when conducting social research in the prison setting (ibid).

Since 1972, the world, led by America, has been on an incarceration binge. Millions of men, women, and children are now confined in some form of imprisonment, and the number is growing every day, with seemingly no end in sight. With the imprisonment of millions of people, much has changed in the prison since 1972, when Herbert Kelman thought that prisoners "by their very nature" could not provide investigators (Kelman, 1972, p. 994). The prison has developed as a microcosmic mirror society. Although it is distorted and twisted in some respects, this society also resembles normal society in many other respects. In prisons, many people perform various kinds of work-tasks and attend vocational classes or academic courses; they attend medical appointments for treatment, and chapels for worship; they sit down with others for meals, make telephone calls, play sports and engage in many normal types of other social, economic and personal activities.

Considering the development of the prison since 1972 as a fully-fledged microcosmic society in its own right, the following question needs to be asked: is there a possibility that prisoners can be trained as researchers and conduct academic research? The answer may be a surprise to many academics, but yes, of course people in prison can conduct academic research. There are imprisoned intellectuals who are politically and 
academically engaging with the social, racial, cultural, legal, and other aspects of their confinement and the place of the prison in society (James, 2003; Rodríguez, 2006). Professor Dylan Rodríguez (2006, p. 10) of UC Riverside and a founding member of Critical Resistance says that

Confronted with the dilemma of how to foster substantive political, intellectual, and personal connections to political affiliates and loved ones in civil society, imprisoned radical intellectuals appropriate their conditions of confinement to generate a body of social thought that antagonizes and potentially disrupts the structuring logic of their own civic and social death.

That may sound like a surprising claim, but it is true whether in this journal (see Gaucher, 2002; Piché et al., 2014) or elsewhere as authors (for a summary, see Taylor, 2009) and co-authors with university-affiliated academics (see Bosworth et al., 2005; Ross et al., 2014). This article represents the political, sociological, academic, and personal endeavour that Dylan Rodríguez articulates as being possible. It is possible because I have been in prison since 1986, and, in that time, I have obtained all of my academic qualifications and achieved over 40 publications in professional journals. In 1986, at 23 years of age, I was functionally illiterate. I could not even spell my middle name, William, because the dyslexia I suffered made the "illi" impossible for me to cope with. But much has changed since then.

My first formal educational achievement came in 2004 when I graduated with a wide-ranging, interdisciplinary Bachelor of Arts Degree with three major humanities sequences of study. In 2005, I was awarded a First Class Honours Degree in Philosophical Studies with a thesis examining the consequentialist utilitarianism of Peter Singer and what it is to live the good life in the age of self-interest and the primacy of the idea in popular culture that material wealth is an ends to happiness and a meaningful life. In February 2012, I was awarded a research $\mathrm{PhD}$ specialising in the field of Applied Ethics and Human and Social Sciences from La Trobe University, Australia. My thesis examined conceptions of the Self and Other surrounding crime and punishment, the accompanying public and private discourse, and the need for this discourse to be mediated by morality. At the time of submitting my thesis, 20 percent of my research had been published in academic journals. 
Despite my origins in criminal activity in the early- to mid-1980s, Dylan Rodríguez (2006, p. 110) would say that I have become an "imprisoned radical intellectual", Black Panther Marshall Eddie Conway would say that I have become a "political prisoner", and Henry Giroux (2005, p. 190) would say that I am an "oppositional academic". The conception of a political prisoner which I have adopted and argued for in other places (Minogue, 2008) is found in the thought of Marshall Eddie Conway, who argues that a political prisoner is a person who

stands up to injustices, a person who for whatever reason takes the position that this or that is wrong, whether they do it based on ideology or they do it based on what they think is morally right... [P] eople become political prisoners, become conscious and become aware and act and behave based on that awareness after they have been incarcerated for criminal activity (Rodríguez, 2006, p. 6).

The "oppositional academic" is a person who challenges the structuring logic of the status quo, as I have done through my publications. This paper is an intellectual and ethical challenge to my imprisonment and to my jailors. This paper is a challenge to the social, legal, academic, ethical, and personal assumptions associated with imprisonment and social research in the prison setting. Whatever frames of reference are argued for, the reality is that imprisoned intellectuals and academics such as myself are already doing the work under the most difficult circumstances imaginable. Imprisoned intellectuals and academics can be contacted, and they can be engaged with by their colleagues on the outside about ethically conducting research on the inside. Alternatively, the university and its academics can just say "the prison allows us to do it" in a kind of weasel-worded version of "just following orders" (Minogue, 2003).

Considering the position I have taken on, the most appropriate way for me to bring this paper to a conclusion is to pose some questions for others to contemplate:

- Will academics outside the prison and their Research Ethics Committees (Institutional Review Boards) think critically about the role and research governance of a malevolent gatekeeper like the prison? 
- Will there be initiatives to engage with imprisoned intellectuals and academics?

- Will innovative ways of working be developed to bypass malevolent gatekeepers like the prison? Or will the role of the malevolent gatekeeper and their unethical research governance continue to be uncritically accepted as the cost of doing research in the prison?

\section{ENDNOTES}

1 I will refer to people by their full proper names, for, as Paul Ricoeur (1992, p. 29) says in his seminal Oneself as Another, "privilege accorded the proper names assigned to humans has to do with their subsequent role in confirming their identity and their selfhood". In most academic disciplines, it is tradition to refer to one's fellows in professional journals by the use of second names only. This is no doubt a kind of shorthand, but it is also a type of elitism and thus a language of exclusion. And "discipline" ends in the academy, as a verb the word "discipline" means the practice of rebuking and imposing obedience and punishment on another person. Such discipline seeks to strip a person of his or her social and human character. The use of family names only is read by me as an objectifying language of exclusion and a form of class elitism, and therefore I break with this tradition whenever I can. It should also be acknowledged that the elimination of given names in research publications is used by some to help rectify the problem of male privilege in the academy. Research has shown that gender-bias can result when the sex of the author or authors is known to reviewers and readers who tend to associate greater scientific quality with scholarship by men, irrespective of merit (Knobloch-Westerwick et al., 2013). However, from where I am writing from, where prisoners are stripped of their identity through practices such as not calling them by their given names, I feel including them is necessary here as an act of humanization and acknowledgement.

2 These ideas have been taken from Christopher Shea's article "Don't Talk to the Humans: The Crackdown on Social Science Research". This article was sent to me by one of the peer reviewers, but it did not have a URL, or page numbers, or any details about when and where, if anywhere, it had been published. I do not have access to the internet or a university library, and, after 28 years in prison, the number of people I can call on for any type of support has dwindled to next to nothing-and there is only so much my long suffering, now 75-year-old mother can do, in terms of academic research support. Reviewers also suggested the need for more academic journal article references to support my argument and more up-to-date materials. I have done as much as I can from the site of isolation and marginalisation in which I find myself. Academics in the real world with all the resources at their fingertips need to take up the challenge that this insider article presents.

\section{REFERENCES}

Alford, C. Fred (2000) "What Would It Matter If Everything Foucault Said About Prisons Were Wrong? Discipline and Punish After Twenty Years", Theory and Society, 29(1): 125-146. 
Bosworth, Mary, Debi Campbell, Bonita Demby, Seth M. Ferranti and Michael Santos (2005) "Doing Prison Research: Views From Inside", Qualitative Inquiry, 11(2): 249-264.

Corrections Research Agenda 2009-2012 (2009) Department of Justice, Melbourne, Victoria.

Corrections Research Strategy 2009-2012 (2009) Department of Justice, Melbourne, Victoria.

CV-DOJ (2011). Retrieved from http://www/justice.vic.gov.au/wps/wcm/connect/ justlib/CV-DOJ+internet.

DPP v Federico [2005] VSC 470, unreported, Cummings, J., 1 December 2005, transcript of proceeding, Ruling, pp. 603-608.

Foucault, Michel (1991) Discipline and Punish: The Birth of the Prison, Alan Sheridan (trans.), London: Penguin Books.

Gaucher, Bob (ed.) (2002) Writing as Resistance: The Journal of Prisoners on Prisons Anthology (1988-2002), Toronto: Canadian Scholars' Press.

Gifford, D.J. and K. Gifford (1994) How to Understand an Act of Parliament (eighth edition), Sydney: The Law Book Company Ltd.

Giroux, Henry (2005) Against the New Authoritarianism: Politics After Abu Ghraib, Winnipeg: Arbeiter Ring Publishing.

Haney, Craig, Curtis Banks and Philip G. Zimbardo (1973) "Interpersonal Dynamics in a Simulated Prison", Intemational Journal of Criminology and Penology, 1: 69-97.

James, Joy (2003) Imprisoned Intellectuals: Americas Political Prisoners Write on Life, Liberation and Rebellion, Lanham (MD): Rowman \& Littlefield Publishing Inc.

Kelman, Herbert C. (1972) "The Rights of the Subject in Social Research: An Analysis in Terms of Relative Power Legitimacy", American Psychologist, 27: 989-1016.

Knobloch-Westerwick, Silvia, Caroll. J. Glynn and Michael Huge (2013) "The Matilda Effect in Science Communication: An Experiment on Gender Bias in Publication Quality Perceptions and Collaboration Interest", Science Communication, 35: 603-625.

Milgram, Stanley (1974) Obedience to Authority: An Experimental View, London: Tavistock Publications.

Minogue, Craig (2011) "Is the Foucauldian Conception of Disciplinary Power Still at Work in Contemporary Forms of Imprisonment?", Foucault Studies, 11: 178-192.

Minogue, Craig (2010) "A Pedagogy of Resistance: A Hidden History of Mass Work on a Minor Scale", Review of Education, Pedagogy \& Cultural Studies, 32(3): 323-336.

Minogue, Craig (2009) "The Engaged Specific Intellectual: Resisting Unethical Prison Tourism and the Hubris of the Objectifying Modality of the Universal Intellectual", Journal of Prisoners on Prisons, 18(1\&2): 129-142.

Minogue, Craig (2008) "Political Prisoners in Australia?", Journal of Prisoners on Prisons, 17(2): 53-57.

Minogue, Craig (2005) "The Use of a Military Level of Force on Civilian Prisoners: Strip Searching, Urine Testing, Cell Extractions and DNA Sampling In Victoria", Alternative Law Journal, 30(4): 170-173.

Minogue, Craig (2003) "Human Rights and Life as an Attraction in a Correctional Theme Park", Journal of Prisoners on Prisons, 12: 44-57.

Minogue, Craig (2002) “An Insider's View: Human Rights and Excursions From the Flat Lands", in David Brown and Meredith Wilkie (eds.), Prisoners as Citizens: Human Rights in Australian Prisons, Annandale (NSW): The Federation Press, pp. 196-212.

Minogue v Australia [2004] UNHCR 52. 
Minogue v Human Rights and Equal Opportunity Commission [1998] Vol. 54 Administrative Law Decisions, p.389; and Vol. 84 Federal Court Reports, p.438.

Minogue v Human Rights and Equal Opportunity Commission [1998] Vol. 166 Australian Law Reports, p.29; and Vol. 57 Administrative Law Decisions, p.23.

National Statement on Ethical Conduct in Human Research [NSECHR] (2007) Australian Government, Canberra.

Piché, Justin, Bob Gaucher and Kevin Walby (2014) "Facilitating Prisoner Ethnography: An Alternative Approach to 'Doing Prison Research Differently'", Qualitative Inquiry, 20(4): 392-403.

Piché, Justin and Kevin Walby (2010) "Problematizing Carceral Tours", British Journal of Criminology, 50(3): 570-581.

Ricoeur, Paul (1992) Oneself as Another, Chicago: The University of Chicago Press.

Rodríguez, Dylan (2006) Forced Passages: Imprisoned Radical Intellectuals and the U.S. Prison Regime, Minneapolis: University of Minnesota Press.

Ross, Jeffrey I., Miguel Zaldivar and Richard Tewksburry (2014) "Breaking Out of Prison and into Print? Rationales and Strategies to Assist Educated Convicts Conduct Scholarly Research and Writing Behind Bars", Critical Criminology, Online First, 11 pages.

The Macquarie Dictionary (1981) St. Leonards (NSW): Macquarie Library.

Singer, Peter (1986) Applied Ethics, Oxford: Oxford University Press.

Smith, Hayden P. (2012) "Reinforcing Experiential Learning in Criminology: Definitions, Rationales, and Missed Opportunities Concerning Prison Tours in the United States", Journal of Criminal Justice Education, 24(1): 1-18.

Wacquant, Loïc (2002) "The Curious Eclipse of Prison Ethnography in the Age of Mass Incarceration”, Ethnography, 3(4): 371-397.

\section{ABOUT THE AUTHOR}

Craig W. J. Minogue has survived in prison since 1986. Having completed a BA (Hons) in 2005, he was awarded a research based PhD in Applied Ethics in February 2012. Craig assists fellow prisoners with equitable access to the courts, educational programs and health services. He is a regular contributor to community education projects and has over 45 publications in philosophy, literature, criminal law, human rights, and prison issues. Craig can be contacted by email at craig2016@bigpond.com or by mail at the following address:

Craig Minogue

Locked Bag 3

Castlemaine, Victoria

Australia 3450 